\title{
Eksplorasi Kemampuan Siswa Memecahkan Masalah Program Linier Grafik dan Soal Cerita
}

\author{
Ita Chairun Nissa
}

Universitas Pendidikan Mandalika

itachairunnissa@ikipmataram.ac.id

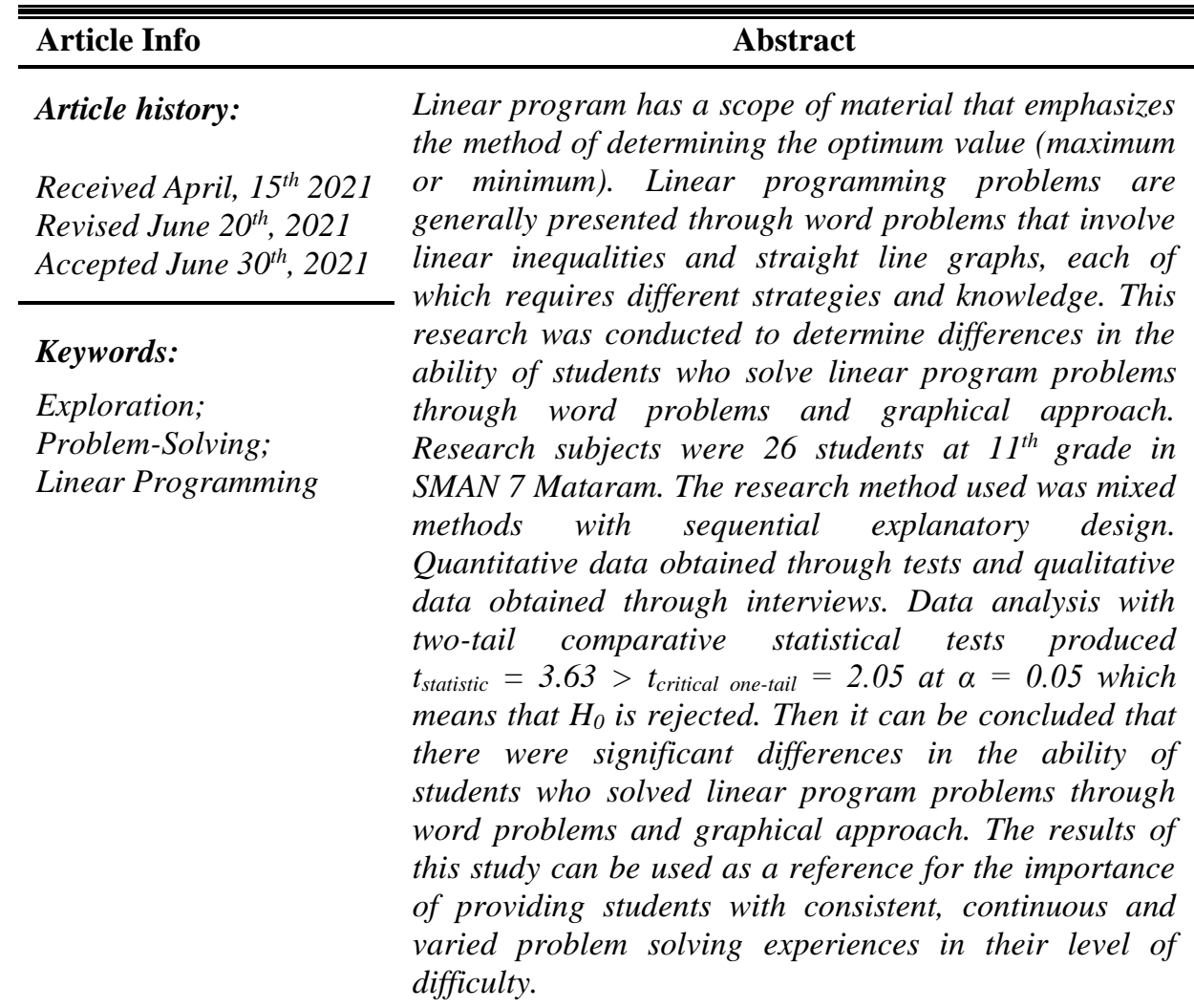

Kata Kunci:

Program linier memiliki muatan materi yang

Eksplorasi;

Pemecahan Masalah; menekankan pada metode penentuan nilai optimum Program Linier (maksimum atau minimum). Masalah program linier pada umumnya disajikan dalam bentuk soal cerita yang melibatkan pertidaksamaan linier dan grafik garis lurus yang masing-masing memerlukan strategi dan pengetahuan yang berbeda. Penelitian ini dilakukan untuk mengetahui perbedaan kemampuan siswa yang memecahkan masalah program linier dalam bentuk soal 
cerita dan dalam bentuk grafik. Subjek penelitian sebanyak 26 siswa kelas XI SMAN 7 Mataram. Metode penelitian yang digunakan adalah mixed methods dengan desain eksplanatoris sekuensial. Data kuantitatif diperoleh melalui tes dan data kualitatif diperoleh melalui wawancara. Analisa data dengan uji statistik komparatif dua pihak menghasilkan $t_{\text {statistik }}=3.63>t_{\text {kritis satu pihak }}=2.05$ pada $\alpha=0.05$ yang artinya $\mathrm{H}_{0}$ ditolak. Sehingga dapat disimpulkan bahwa ada perbedaan yang signifikan atas kemampuan siswa yang memecahkan masalah program linier dalam bentuk soal cerita dan dalam bentuk grafik. Hasil penelitian ini dapat dijadikan rujukan bagi pentingnya memberikan pengalaman pemecahan masalah kepada siswa secara konsisten, berkelanjutan dan beragam dalam tingkat kesukarannya.

\section{PENDAHULUAN}

Matematika memainkan peranan yang besar dalam mengembangkan pemikiran manusia, membawa proses pemikiran strategis dan sistematis yang digunakan dalam analisis dan pemecahan masalah. Kemampuan ini membantu seseorang untuk dapat mengantisipasi, merencanakan, memutuskan, dan menyelesaikan masalah dalam kehidupan sehari-hari dengan tepat. Pemecahan masalah matematika di sekolah biasanya diwujudkan melalui soal cerita. Dalam penyelesaian soal cerita, terlebih dahulu siswa harus dapat memahami isi soal cerita, mampu memisalkan objek-objek dalam masalah dalam bentuk simbol-simbol matematika, sampai pada tahap akhir penyelesaian dan menemukan solusi (Hanifah, 2011). Namun, kenyataannya siswa seringkali mengalami kesulitan dalam menyelesaikan soal cerita daripada soal hitungan (Nurohmah \& Setianingsih, 2014). Kesalahan siswa dalam menyelesaikan soal cerita pada umumnya terletak pada kesalahan dalam memahami bahasa yang menyebabkan siswa kesulitan mengidentifikasi data yang diketahui (Ningrum, 2013).

Program linier merupakan salah satu materi matematika wajib di tingkat SMA. Materi ini berkaitan dengan masalah optimalisasi (minimum dan maksimum) fungsi linier karena adanya kendala atau 
pembatasan pada persamaan dan/atau pertidaksamaan linier. Masalahmasalah matematika terkait program linier cukup diminati karena program linier mampu untuk memodelkan suatu masalah yang besar dan kompleks, mampu untuk memecahkan masalah tersebut dalam waktu yang rasional dengan menggunakan algoritma yang efektif (Bazaraa, Jarvis, \& Sherali, 2011). Program linier merepresentasikan banyak hal terkait dengan permasalahan rutin yang sering ditemui dalam kehidupan sehari-hari (Vanderbei, 2015).

Beberapa penelitian terkait kemampuan siswa dalam memecahkan masalah program linier telah dilakukan. Hasil penelitian yang dilakukan terhadap siswa SMA di Denpasar menunjukkan bahwa kemampuan siswa masih rendah dalam menyelesaikan masalah program linier dalam bentuk soal cerita (Asih, 2011). Kesalahan siswa disebabkan oleh kesalahan interpretasi bahasa, kesalahan prosedur, dan kesalahan teknis. Begitu pula diketahui bahwa kemampuan siswa SMK di Jember masih tergolong rendah dalam hal memahami masalah sehingga siswa mengalami kesulitan dalam menyusun rencana untuk menentukan solusi. Selain itu siswa juga masih mengalami kesalahan dalam mengubah kalimat verbal menjadi model matematika (Ninik, Hobri, \& Suharto, 2014). Penelitian serupa terhadap siswa SMK di Bondowoso menunjukkan bahwa kemampuan siswa masih lemah pada aspek memahami masalah dan mentransfer informasi menjadi variabel, kesalahan dalam melakukan prosedur matematika dan kesalahan dalam penarikan kesimpulan (Mustaqim, 2013).

Berbagai penelitian yang telah dilakukan sebelumnya, menitikberatkan bahwa tahapan memahami masalah menjadi kunci penting keberhasilan siswa dalam pemecahan masalah. Kesalahan pada tahap tersebut sangat mempengaruhi berhasil atau tidaknya siswa menemukan strategi menuju solusi. Akan tetapi, berbagai penelitian tersebut sebagian besar menggunakan tes program linier dalam bentuk soal cerita. Belum ada penelitian yang mencoba menggunakan tes program linier dalam bentuk grafik. Bentuk soal tes yang diberikan kepada siswa perlu menjadi perhatian khusus karena kemampuan siswa yang sangat beragam di dalam kelas. Berdasarkan asumsi bahwa proses 
memecahkan masalah matematika dalam bentuk soal cerita dan grafik memerlukan strategi yang berbeda, maka kami mengajukan hipotesis penelitian yaitu ada perbedaan kemampuan siswa yang memecahkan masalah program linier dalam bentuk soal cerita dan grafik. Dalam penelitian ini juga dijelaskan mengenai penyebab adanya perbedaan tersebut termasuk kreativitas berpikir siswa dan kesalahan yang mungkin muncul.

\section{METODE PENELITIAN}

Penelitian ini dilakukan di SMA Negeri 7 Mataram dengan subjek penelitian sebanyak 26 orang siswa kelas XI IPA 1. Pemilihan subjek penelitian dilakukan dengan cara purposive sampling dimana siswa dipilih berdasarkan variasi kemampuan matematika dan komunikasinya yang baik. Metode penelitian yang digunakan adalah mixed methods karena proses penelitian ini melibatkan pengumpulan data, analisis dan pengintegrasian data kuantitatif dan kualitatif. Desain penelitian yang digunakan adalah desain eksplanatoris sekuensial melalui dua fase yaitu fase kuantitatif dan fase kualitatif. Fase kualitatif dibangun berdasarkan data kuantitatif yang berfungsi untuk mendeskripsikan data yang telah diperoleh pada fase kuantitatif. Data kuantitatif dalam penelitian ini adalah hasil tes sedangkan data kualitatifnya adalah hasil wawancara.

Strategi siswa dalam memecahkan masalah program linier merujuk pada strategi pemecahan masalah heuristik (Schoenfeld, 2014), sedangkan kinerja siswa dalam melakukan pemecahan masalah tersebut dinilai menggunakan rubrik holistik (Rosli, Goldsby, \& Capraro, 2013). Rubrik ini menilai kinerja pemecahan masalah secara kuantitatif dalam bentuk skor yang ditujukan pada tiga tahap saja yaitu memahami masalah, menyusun rencana, dan menjalankan rencana. Sedangkan tahap keempat yaitu melihat kembali cenderung untuk dinilai secara kualitatif. Rubrik holistik untuk menilai kinerja pemecahan masalah siswa ditunjukkan pada Tabel 1.

Teknik analisis data kuantitatif yang digunakan dalam penelitian ini adalah analisa data statistik komparasi dua sampel dengan uji $t$. Uji $t$ yang dilakukan bertujuan untuk menguji hipotesis dengan kriteria pengujian 
yaitu apabila $-t_{\text {kritis satu pihak }} \leq t_{\text {statistik }} \leq+t_{\text {kritis satu pihak }}$ maka $\mathrm{H}_{0}$ diterima pada $\alpha=0.05$. Adanya perbedaan yang signifikan terhadap hasil tes siswa dapat diartikan bahwa ada perbedaan kemampuan siswa dalam memecahkan masalah program linier dalam bentuk soal cerita dan grafik. Sementara itu, teknik analisis data kualitatif yang digunakan dalam penelitian ini ada tiga tahap yaitu reduksi data, penyajian data, dan penarikan kesimpulan.

\section{Tabel 1. Rubrik Holistik Pemecahan Masalah}

\begin{tabular}{|c|c|c|}
\hline Tahapan & Skor & Kriteria Penilaian \\
\hline \multirow{3}{*}{$\begin{array}{l}\text { Memahami } \\
\text { masalah }\end{array}$} & 2 & Memahami masalah secara lengkap \\
\hline & 1 & Beberapa bagian dari masalah disalahtafsirkan \\
\hline & 0 & Kesalahpahaman total mengenai masalah \\
\hline \multirow[t]{3}{*}{$\begin{array}{l}\text { Menyusun } \\
\text { rencana }\end{array}$} & 2 & $\begin{array}{l}\text { Rencana diaplikasikan dengan tepat sehingga } \\
\text { menghasilkan solusi yang benar }\end{array}$ \\
\hline & 1 & $\begin{array}{l}\text { Rencana sebagian benar berdasarkan bagian dari } \\
\text { masalah yang ditafsirkan dengan benar }\end{array}$ \\
\hline & 0 & $\begin{array}{l}\text { Tidak memiliki rencana atau memiliki rencana tetapi } \\
\text { tidak tepat }\end{array}$ \\
\hline \multirow{3}{*}{$\begin{array}{l}\text { Menjalankan } \\
\text { rencana }\end{array}$} & 2 & Menghasilkan jawaban yang benar \\
\hline & 1 & $\begin{array}{l}\text { Terdapat kesalahan komputasi, jawaban parsial } \\
\text { untuk masalah yang banyak jawaban }\end{array}$ \\
\hline & 0 & $\begin{array}{l}\text { Tidak ada jawaban atau jawaban salah berdasarkan } \\
\text { rencana yang tidak tepat }\end{array}$ \\
\hline
\end{tabular}

\section{HASIL PENELITIAN DAN PEMBAHASAN}

Aktivitas utama yang mendasari penelitian ini adalah merancang tes pemecahan masalah pada materi program linier. Tes dirancang dalam bentuk uraian agar siswa dapat menguraikan langkah-langkahnya secara jelas. Pada penelitian ini tes dalam bentuk soal cerita bersumber dari Buku Matematika SMA/MA/SMK/MAK Kelas IX (Kementerian Pendidikan dan Kebudayaan, 2017). Tes program linier dalam penelitian 
ini terdiri empat soal dimana masing-masing dua soal bentuk soal cerita dan grafik. Soal pertama dari tes program linier dibuat dalam bentuk soal cerita yang menuntut siswa untuk mampu memahami makna bobot nilai tes dan penggunaan operasi matematika yang tepat. Ada informasi dalam soal yang tidak disebutkan secara eksplisit yaitu informasi nilai maksimal dari suatu nilai tes adalah 100, dimana siswa harus mampu menggali sendiri informasi ini melalui pengalamannya. Berikut soal pertama tersebut.

"Hartono mengikuti ujian akademi kepolisian pada tahun 2020. Sistem ujian yang selektif dan kompetitif mengharuskan setiap peserta ujian harus memiliki nilai gabungan tes tulis dan tes fisik minimal 65 dengan bobot 0.6 untuk tes tulis dan 0.4 untuk tes fisik dengan nilai minimal salah satu tes adalah 55. Berapa nilai tes tulis dan tes fisik yang harus diperoleh Hartono agar dapat lulus ujian?"

Soal kedua dari tes program linier disusun dalam bentuk soal cerita yaitu menyajikan informasi penting dengan lebih sedikit bilangan, sehingga siswa harus mampu menggali sendiri informasi tersebut melalui pengalamannya. Selain itu, terdapat informasi yang sebenarnya tidak diperlukan dalam proses perhitungan matematika yaitu lahan berbentuk persegi panjang. Siswa mungkin dapat berpikir bahwa mereka perlu menentukan ukuran panjang dan lebar dari lahan tersebut. Siswa yang memiliki intuisi yang baik akan memiliki wawasan bahwa masalah ini sebenarnya terkait dengan program linier, khususnya kemampuan untuk menyelesaikan pertidaksamaan linier yang dicirikan melalui kata kunci "lebih luas". Masalah ini memuat berbagai kemungkinan jawaban benar walaupun tidak dinyatakan secara eksplisit dalam soal. Siswa diminta menentukan luas lahan yang mungkin untuk ditanami jagung dan kentang berdasarkan situasi yang dialami petani. Siswa yang memiliki pemikiran kritis akan mencoba menentukan lebih dari satu jawaban, karena melalui kata kunci "mungkin" yang mengindikasikan ada jawaban lain yang juga menjadi solusi dari masalah tersebut. Berikut soal kedua tersebut. 
"Seorang petani di desa memiliki lahan berbentuk persegi panjang seluas $600 \mathrm{~m}^{2}$. Dia hendak menanam jagung dan kentang di lahan tersebut. Saat ini petani itu tidak memiliki cukup modal untuk menanami seluruh lahannya, tetapi dia ingin lahannya lebih luas ditanami kentang. Berapa luas lahan yang mungkin untuk ditanami jagung dan kentang?"

Soal ketiga disajikan dalam bentuk grafik. Soal ini membutuhkan kemampuan yang berbeda dibandingkan dengan tes dalam bentuk soal cerita. Siswa harus mampu menginterpretasikan grafik ke dalam bentuk persamaan garis lurus dengan menentukan dua titik potong garis terhadap sumbu koordinat $x$ dan $y$. Terdapat informasi dalam soal bahwa nilai maksimum diperoleh pada titik $\mathrm{K}$, dimana informasi ini akan memunculkan berbagai macam penafsiran daerah penyelesaian. Soal ketiga tersebut dapat dilihat pada Gambar 1.

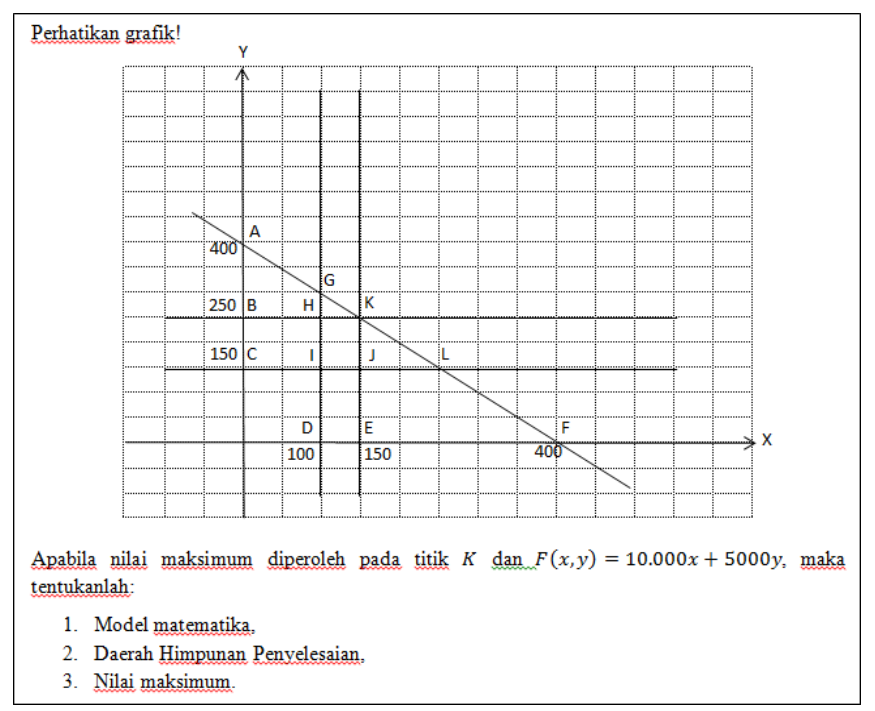

\section{Gambar 1. Soal Ketiga Tes Program Linier Representasi Grafik}

Soal keempat tes program linier representasi grafik dirancang serupa seperti pada soal sebelumnya, namun berbeda dalam hal informasi yang diberikan dimana telah diketahui dua garis yaitu garis $x \leq 6$ dan garis $y \geq 4$. Soal keempat tersebut dapat dilihat pada Gambar 2 . 


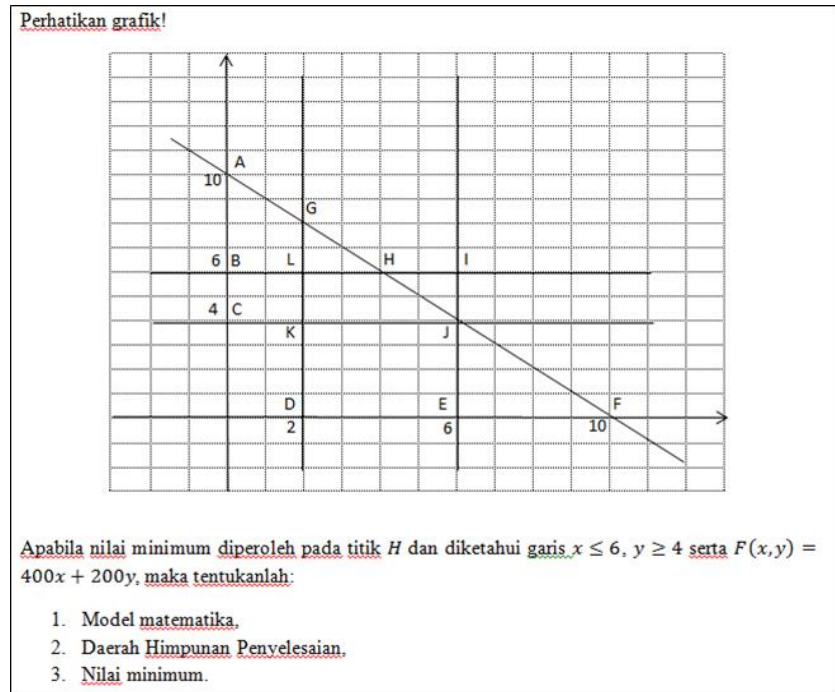

\section{Gambar 2. Soal Keempat Tes Program Linier Representasi Grafik}

Keempat masalah matematika yang diberikan kepada siswa baik melalui tes dalam bentuk soal cerita mapun tes dalam bentuk grafik, ternyata memberikan hasil yang beragam. Namun, ada kesamaan diantara keduanya yaitu sebagian besar siswa masih belum mampu berpikir kritis terhadap data penting dalam soal yang tidak disebutkan secara langsung. Siswa juga belum mampu menafsirkan bahwa masalah yang diberikan menghasilkan beberapa jawaban benar. Hasil tes siswa tersebut secara kuantitatif dianalisis secara statistik menggunakan fitur data analysis tool pada Ms. Excel. Analisa data statistik komparasi dua sampel melalui uji- $t$ dua pihak pada $\alpha=0.05$ telah menghasilkan $t_{\text {statistik }}>t_{\text {kritis satu pihak, }}$, sehingga dalam hal ini $\mathrm{H}_{0}$ ditolak. Dengan demikian dapat dikatakan bahwa ada perbedaan kemampuan siswa yang memecahkan masalah program linier dalam bentuk soal cerita dan dalam bentuk grafik. Tabel 2 menunjukkan ringkasan data uji-t yang dilakukan. 
Tabel 2. $t$-Test: Paired Two Sample for Means

\begin{tabular}{lcc}
\hline \multicolumn{1}{c}{ Ukuran Pemusatan Data } & Soal Grafik & Soal Cerita \\
\hline Mean & 53.846 & 45.192 \\
\hline Variance & 84.615 & 100.962 \\
\hline Observations & 26 & 26 \\
\hline Pearson Correlation & 0.208 & \\
\hline Hypothesized Mean Difference & 0 & \\
\hline $\mathrm{D}_{\mathrm{f}}$ & 25 & \\
\hline$t$ Stat & 3.638 \\
\hline $\mathrm{P}(\mathrm{T}<=t)$ one-tail & 0.000624 \\
\hline$t$ Critical one-tail & 1.708 \\
\hline $\mathrm{P}(\mathrm{T}<=t)$ two-tail & 0.00125 \\
\hline$t$ Critical two-tail & 2.0595 \\
\hline
\end{tabular}

Adanya perbedaan hasil tes siswa yang ditunjukkan melalui hasil uji statistik tersebut, menunjukkan hal yang serupa dengan deskripsi jawaban siswa. Gambaran kesalahan siswa mengerjakan soal pertama dari tes program linier dalam bentuk soal cerita. Siswa melakukan kesalahan dalam merumuskan model matematika yang disebabkan oleh kegagalan siswa dalam memahami konteks masalah dimana nilai paling tinggi dari suatu tes atau ujian adalah 100. Akibatnya siswa hanya benar sebagian saja dalam menuliskan model matematika seperti yang tampak pada Gambar 3. 


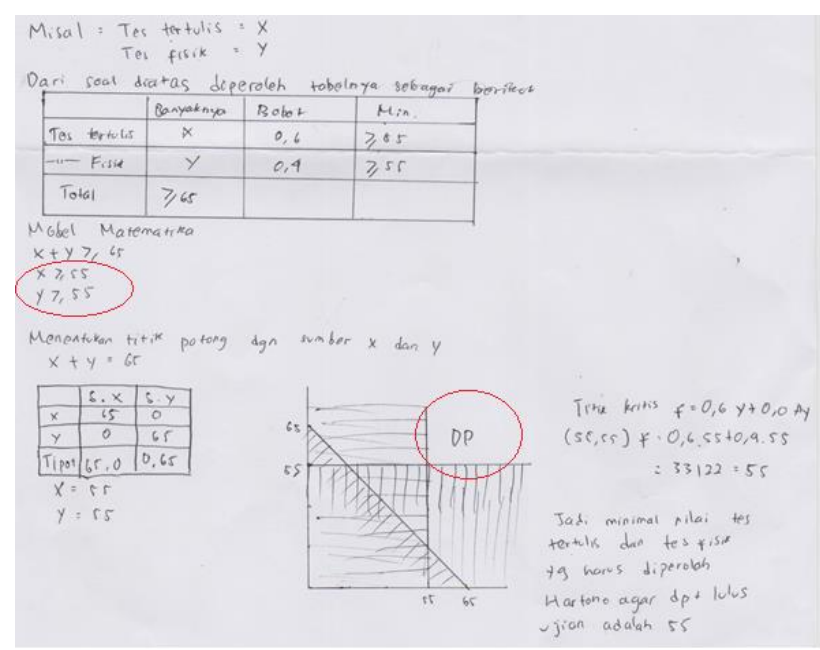

\section{Gambar 3. Contoh Pekerjaan Siswa pada Soal Pertama}

Kesalahan siswa dalam merumuskan model matematika kemudian mengakibatkan kesalahan dalam menentukan daerah penyelesaian, sehingga jawaban yang diberikan tidak sesuai dengan solusi yang diharapkan. Kesalahan siswa disebabkan oleh kurangnya kemampuan siswa dalam mentransformasi kata-kata yang ada dalam soal ke dalam model matematika yang sesuai (Mahmudah, 2017). Hasil wawancara menunjukkan siswa belum memiliki pengalaman dalam memecahkan masalah matematika seperti yang diberikan dalam tes. Selama ini pengalaman siswa hanya terbatas memecahkan masalah program linier dalam bentuk yang sederhana dimana semua informasi penting dinyatakan secara eksplisit dan solusi yang diharapkan merupakan jawaban tunggal. Jadi siswa belum terbiasa untuk mengkritisi suatu masalah. Petikan hasil wawancara dengan salah satu siswa terkait kasus di atas dapat dilihat pada Tabel 3 . 


\section{Tabel 3. Petikan Hasil Wawancara Siswa Tentang Soal Pertama}

Guru : "Bagaimana pendapatmu mengenai soal ini?"

Siswa : "Ehmm... saya bisa mengerjakannya bu, tetapi setelah saya lihat jawaban saya sekarang ternyata ada yang salah"

Guru : "Apakah kamu pernah mengerjakan soal seperti ini sebelumnya?"

Siswa : "Pernah mengerjakan soal program linier, tetapi soal seperti ini belum pernah"

Guru : "Dapatkah kamu jelaskan apa yang membuat kamu bingung?"

Siswa : "Untuk yang ini (menunjuk ke kalimat soal "gabungan tes tertulis dan tes fisik minimal 65"), saya bisa membuat model matematikanya, tetapi yang ini (menunjuk ke kalimat soal "tes harus memiliki nilai minimal 55") membuat saya sedikit bingung"

Guru : "Memangnya seperti apa yang biasa kamu kerjakan"

Siswa : "Biasanya diketahui langsung dua bilangan dan nanti dibuat model matematikanya"

Guru : "Seperti apa model matematikanya?"

Siswa : "Seharusnya seperti ini bu (menunjuk ke model matematika " $x+y \geq 65$ pada lembar jawabannya"), tetapi ini hanya satu bilangan saja yang diketahui jadi saya tuliskan " $x \geq 55$ dan $y \geq 55$ "

Guru : "Apakah kamu pernah mengerjakan suatu tes atau ujian dalam kelas?"

Siswa : "Pernah bu"

Guru : "Apabila kamu dapat mengerjakan semua soal dengan benar, berapa nilai yang kamu peroleh?"

Siswa : "Saya akan mendapat nilai 100”

Guru : "Apakah kamu sudah mengerti sekarang?"

Siswa : "Berarti dalam soal ini diketahui nilai tertinggi pada tes adalah 100 ya bu"

Guru : "Iya betul. Jadi bagaimana model matematika yang harus dibuat?"

Siswa : "Ehmm. apakah seperti ini bu " $x \geq 55$ dan $x \leq 100$ "

Guru : "Coba tuliskan secara benar?"

Siswa : "55 $\leq x \leq 100 "$ begini ya bu?"

Guru : "Iya seharusnya seperti itu model matematikanya?" Dapatkah kamu melakukan hal yang sama untuk variabel nya?" 
Siswa : "Iya bisa bu, tetapi nilai 100 itu kan tidak ada di dalam soal bu?"

Guru : "Iya karena situasinya terkait dengan tes, maka kamu harus menyadari bahwa nilai tes itu paling besar adalah 100 (jika dalam skala 100) atau 10 (jika dalam skala 10).

Pada soal kedua siswa berhasil merumuskan model matematika dengan benar sesuai dengan konteks masalahnya, namun masih melakukan kesalahan dalam langkah-langkah menggambar garis $x-y=$ 0 . Siswa hanya mampu menentukan satu saja titik potong garis $x-y=0$ terhadap sumbu- $x$ dan sumbu-y yaitu (0.0). Seharusnya siswa perlu menentukan satu lagi titik potong agar dapat menggambar garis dengan tepat, namun siswa belum dapat melakukannya. Contoh pekerjaan siswa pada soal kedua dapat dilihat pada Gambar 4.

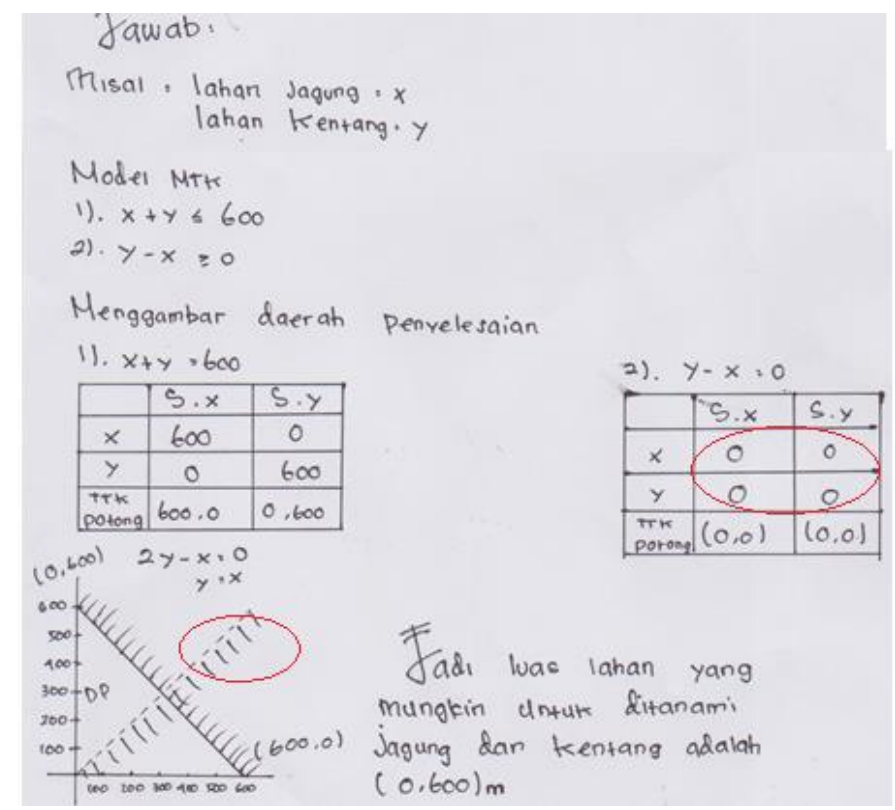

Gambar 4. Contoh Pekerjaan Siswa pada Soal Kedua 
Berdasarkan hasil wawancara dengan salah satu siswa diketahui bahwa pada mulanya siswa merasa kesulitan untuk menggambar garis karena titik potong yang dimiliki hanya titik (0.0). Kemudian karena garis $x+y=600$ berada di Kuadran I (posisi kanan atas), maka siswa mencoba menarik garis yang melalui titik (0.0) tersebut. Kesalahan siswa ini disebabkan karena siswa tidak dapat mengingat kembali prosedur menentukan persamaan garis lurus yang sebenarnya telah mereka pelajari saat di kelas X. Materi persamaan garis lurus merupakan prasyarat untuk mempelajari program linier, sehingga sangat diperlukan sebagai landasan untuk menyelesaikan masalah program linier. Kemampuan siswa mengingat kembali materi yang telah dipelajarinya ternyata merupakan kesalahan yang cukup sering terjadi. Kesalahan ini terjadi disebabkan antara lain siswa kurang menguasai materi prasyarat yaitu pertidaksamaan linier, siswa kurang terampil menuliskan apa yang diketahui dan ditanyakan, dan siswa kurang pengalaman memecahkan masalah dalam variasi yang berbeda (Amaliah, 2018). Tabel 4 menunjukkan petikan hasil wawancara terkait persoalan di atas.

\section{Tabel 4. Petikan Hasil Wawancara Siswa Tentang Soal Kedua}

\begin{tabular}{|c|c|c|}
\hline Guru & : & "Bagaimana kamu dapat menggambar garis $x-y=0 ? "$ \\
\hline Siswa & : & $\begin{array}{l}\text { "Pertama-tama saya menentukan titik potong terhadap sumbu } \\
x \text { dan sumbu y yaitu titik (0.0)" }\end{array}$ \\
\hline Guru & & $\begin{array}{l}\text { "Dapatkah kamu menunjukkan titik (0.0) pada Bidang } \\
\text { Kartesius?" }\end{array}$ \\
\hline Siswa & $\therefore$ & "Iya disini (menunjuk pada titik pusat Bidang Kartesius)” \\
\hline Guru & : & "Adakah titik potong yang lain?" \\
\hline Siswa & & $\begin{array}{l}\text { "Ada. Titik (0.0) juga (sambil menunjuk jawabannya pada } \\
\text { tabel)" }\end{array}$ \\
\hline Guru & : & "Titik itu kan titik yang sama dengan sebelumnya" \\
\hline Siswa & & 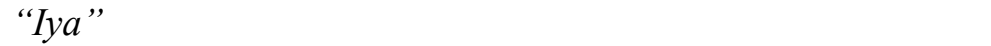 \\
\hline Guru & & $\begin{array}{l}\text { "Jadi bagaimana caramu bisa menggambar garis } x-y=0 \\
\text { pada Bidang Kartesius seperti ini (menunjuk gambar yang } \\
\text { dibuat siswa pada lembar jawabannya)" }\end{array}$ \\
\hline Siswa & & $\begin{array}{l}\text { "Awalnya saya bingung bu, karena titiknya hanya (0.0) saja. } \\
\text { Terus saya lihat garis yang satunya (garis } x+y=600) \text { berada } \\
\text { di sebelah sini (menunjuk kuadran I), maka saya buat saja } \\
\text { garisnya yang mengarah ke daerah ini (menunjuk kuadran I)" }\end{array}$ \\
\hline
\end{tabular}


Guru : "Apakah kamu sebelumnya pernah mengerjakan soal membuat garis yang telah diketahui persamaannya?"

Siswa : "Pernah bu"

Guru : "Mengapa kamu masih bingung?"

Siswa : "Saya lupa bu, itu sudah lama saat saya di kelas X"

Berdasarkan hasil tes dan wawancara dengan siswa yang memecahkan masalah program linier dalam bentuk soal cerita, dapat dijelaskan bahwa siswa masih mengalami kesulitan pada tahap memahami masalah dan belum dapat memberikan berbagai kemungkinan jawaban benar seperti yang diharapkan dalam soal. Secara umum, kesalahan tersebut disebabkan minimnya pengalaman siswa dalam memecahkan berbagai masalah program linier sehingga siswa belum mampu berpikir kritis terhadap apa yang ia hadapi. Kesalahan siswa pada tahap ini kemudian berdampak pada tahapan pemecahan masalah selanjutnya. Dengan demikian, tahap memahami masalah dapat dikatakan sebagai suatu titik kritis dari kemajuan kinerja siswa yang sangat menentukan apakah ia akan sukses pada tahap pemecahan masalah selanjutnya. Keberhasilan siswa membuat model matematika akan menjadi dukungan terbaik dalam menyusun rencana dan melaksanakannya secara benar.

Namun hasil berbeda ditunjukkan pada hasil tes siswa yang memecahkan masalah program linier dalam bentuk grafik dimana hasilnya lebih baik dibandingkan dengan tes dalam bentuk soal cerita. Hal ini ditunjukkan dengan sebagian besar langkah siswa dalam menjawab soal sudah benar. Selain itu, jawaban siswa pada tes ini nampak lebih beragam dengan munculnya beberapa kemungkinan daerah penyelesaian yang memenuhi. Jadi secara umum sebagian besar siswa mampu menjawab tes yang diberikan walaupun masih terdapat beberapa kesalahan kecil dalam melakukan perhitungan matematika. Contoh pekerjaan siswa pada soal ketiga dapat dilihat pada Gambar 5. 


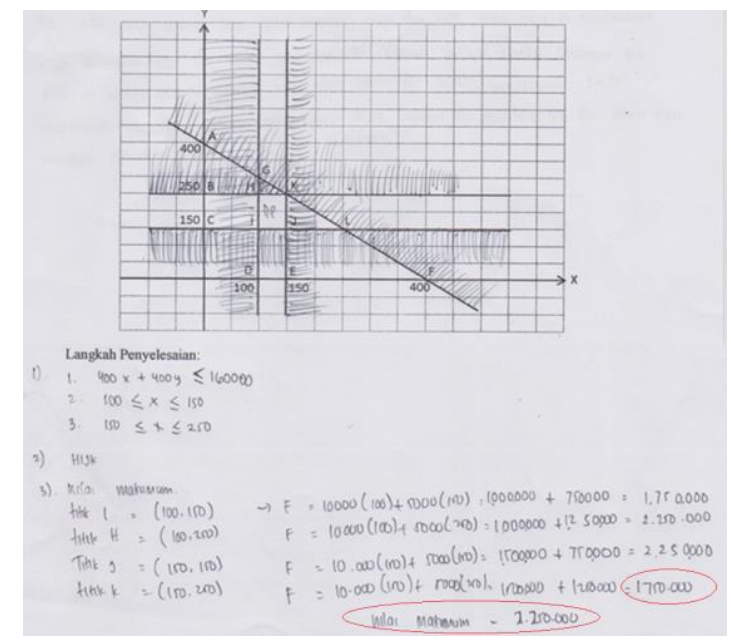

\section{Gambar 5. Contoh Pekerjaan Siswa pada Soal Ketiga}

Pada Gambar 5, nampak siswa mampu membuat model matematika dengan benar sedemikian sehingga memenuhi persyaratan bahwa nilai maksimum berada pada titik K. Model matematika yang benar ini kemudian mengarahkan siswa pada penentuan daerah penyelesaian yang juga benar. Namun, pada saat siswa ingin menentukan nilai maksimum dari daerah penyelesaian tersebut siswa melakukan sedikit kesalahan perhitungan matematika sehingga jawaban yang diberikan tidak sesuai dengan yang diharapkan. Dalam proses memecahkan masalah matematika siswa terkadang melakukan kecerobohan dalam melakukan operasi hitung matematika (Wildana, Mustamin, \& Nur, 2016). Kemampuan siswa memecahkan soal ketiga seharusnya dapat menjadi pengalaman untuk memecahkan soal keempat namun ternyata terdapat lebih banyak kesalahan yang dilakukan. Contoh pekerjaan siswa pada soal keempat dapat dilihat pada Gambar 6. 


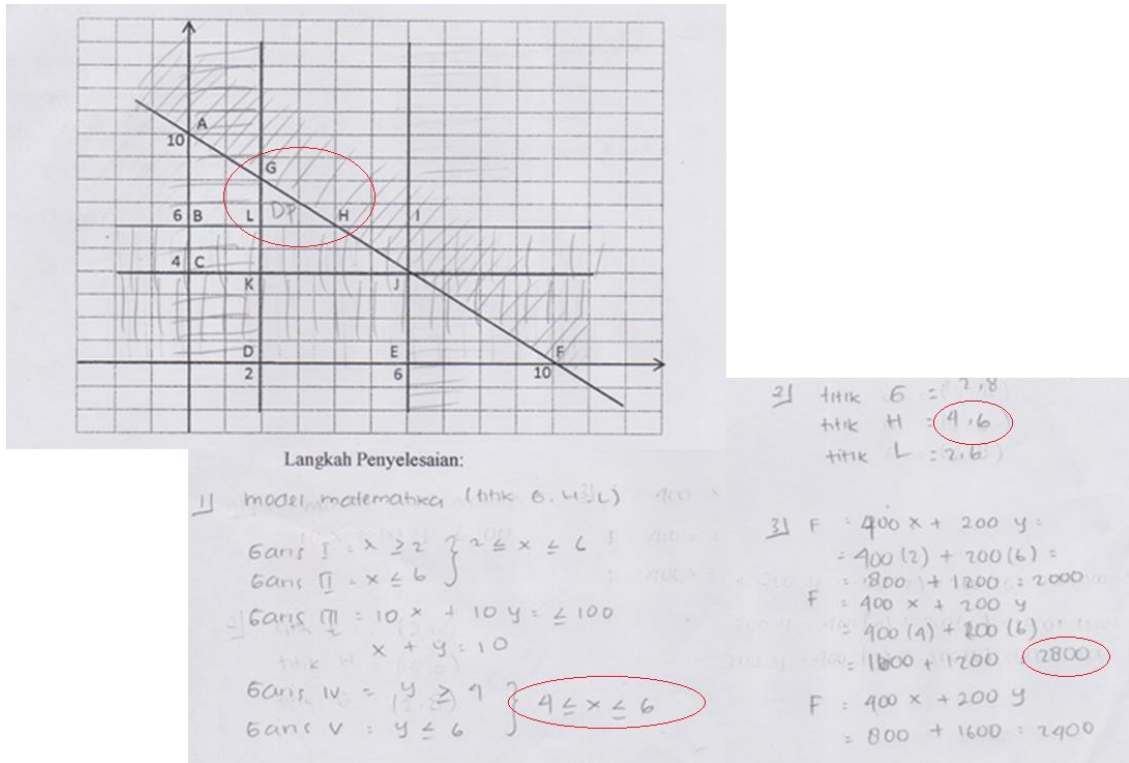

Gambar 6. Contoh Pekerjaan Siswa pada Soal Keempat

Pada Gambar 6, nampak bahwa siswa tidak memperhatikan persyaratan yang telah diberikan dalam soal bahwa nilai minimum diperoleh pada titik $H$. Seharusnya siswa dapat melihat kembali jawabannya dan menemukan kontradiksi antara apa yang diketahui dengan jawaban yang diperoleh. Pada kasus ini sebenarnya telah diketahui bahwa nilai minimum diperoleh pada titik $\mathrm{H}$, tetapi hal ini tidak sesuai dengan hasil perhitungan yang menunjukkan nilai fungsi pada titik $\mathrm{H}$ adalah paling besar dibandingkan dengan titik $\mathrm{G}$ dan titik $\mathrm{L}$. Berdasarkan hasil wawancara dengan siswa diketahui bahwa siswa tidak memperhatikan dengan seksama kalimat soal. Siswa beranggapan bahwa yang harus ditentukan adalah nilai maksimum sama seperti pada soal ketiga sebelumnya. Kesalahan siswa seperti ini sejalan dengan penelitian yang menyatakan bahwa salah satu kesalahan siswa dalam memecahkan masalah program linier adalah kesalahan prinsip dalam menentukan nilai minimum yang disebabkan oleh kesalahan memahami fakta atau istilah yang dinyatakan secara eksplisit (Bahar, 2013).

Perbedaan kemampuan siswa memecahkan masalah program linier dalam bentuk soal cerita dan grafik yang telah diuraikan dalam penelitian 
ini memberikan gambaran kepada kita bahwa konteks masalah matematika yang diberikan kepada siswa dapat mempengaruhi cara berpikir mereka. Soal cerita menuntut siswa untuk mampu memahami masalah sesuai konteksnya yang kemudian dirumuskan dalam model matematika. Prinsip ini menjadi tantangan bagi siswa yang minim pengalaman pemecahan masalah sehingga beberapa kesalahan terjadi secara konseptual. Begitu pula soal matematika dalam bentuk grafik yang juga menantang representasi visual siswa. Siswa harus mampu menginterpretasikan grafik dengan tepat sehingga dapat diketahui maknanya. Pada akhirnya, kedua bentuk soal matematika tersebut sangat diperlukan dalam pembelajaran matematika untuk meningkatkan variasi pengalaman siswa memecahkan masalah matematika. Semakin kaya pengalaman siswa dalam memecahkan masalah maka akan semakin meningkatkan kemampuan siswa dalam memahami masalah, menyusun rencana dan menjalankannya untuk memperoleh solusi yang sesuai dengan konteks masalah yang diberikan.

\section{SIMPULAN}

Berdasarkan hasil uji hipotesis yang telah dilakukan dalam penelitian ini maka dapat disimpulkan bahwa ada perbedaan kemampuan siswa yang memecahkan masalah program linier dalam bentuk soal cerita dan dalam bentuk grafik. Perbedaan ini disebabkan karena memahami masalah dalam bentuk soal cerita lebih sulit dibandingkan dengan masalah dalam bentuk grafik. Kegagalan siswa dalam mengingat kembali materi sebelumnya yang pernah dipelajari juga mempengaruhi kelancaran siswa dalam menyusun rencana pemecahan masalah. Selain itu, pengalaman siswa yang minim dalam menghadapi berbagai jenis soal matematika juga membuat siswa menjadi kurang kritis dalam menganalisa informasi penting dalam soal maupun memeriksa solusinya. Oleh karena itu, hasil penelitian ini diharapkan dapat memberikan rujukan dalam hal pentingnya memberikan pengalaman pemecahan masalah matematika kepada siswa secara konsisten, berkelanjutan dan beragam dalam tingkat kesukarannya. Gagasan dari penelitian ini selanjutnya akan 
dikembangkan untuk merancang soal matematika yang tidak hanya memiliki multi jawaban tetapi juga multi strategi.

\section{DAFTAR PUSTAKA}

Amaliah, A. I. (2018). Analisis Kesalahan Peserta Didik Dalam Menyelesaikan Soal Program Linier Pada Kelas XII IPA SMA Negeri 7 Mataram Semester Ganjil Tahun Ajaran 2017/2018. Unpublished Thesis. Mataram: Universitas Mataram.

Asih, I. . (2011). Peningkatan Kemampuan Siswa SMAN 8 Denpasar Dalam Menyelesaikan Soal Cerita Pokok Bahasan Program Linear Mata Pelajaran Matematika. Udayana Mengabdi, 10(2), 67-71.

Bahar. (2013). Investigasi Karakteristik Kesalahan Siswa SMK Dalam Pemecahan Masalah Soal Cerita Program Linier Ditinjau dari Kemampuan Awal. Unpublished Thesis. Makasar: Universitas Negeri Makasar.

Bazaraa, M. S., Jarvis, J. J., \& Sherali, H. D. (2011). Linear Programming and Network Flows. Retrieved from http://marefateadyan.nashriyat.ir/node/150.

Hanifah, E. H. (2011). Identifikasi kesalahan siswa dalam menyelesaikan soal Cerita Matematika materi Sistem Persamaan Linier Dua Variabel berdasarkan metode analisis kesalahan Newman: studi kasus SMP Bina Bangsa Surabaya. Unpublished Thesis. Surabaya: IAIN Sunan Ampel Sur.

Kementerian Pendidikan dan Kebudayaan, R. I. (2017). Buku Guru Matematika Untuk SMA/MA/SMK/MAK Kelas IX. Jakarta: Kementerian Pendidikan dan Kebudayaan RI.

Mahmudah, I. D. (2017). Kesalahan Siswa Dalam Menyelesaian Soal Program Linier Bentuk Cerita Berbasis Newman di MAN Salatiga. Unpublised Thesis. Surakarta: Universitas Muhammad.

Mustaqim. (2013). Proses Scaffolding Berdasarkan Diagnosis Kesulitan Siswa dalam Menyelesaikan Masalah Program Linear dengan Menggunakan Mapping Mathematics. Jurnal Pendidikan Sains, 1(1), 72-78. Retrieved from http://journal.um.ac.id/inde. 
Ningrum, L. S. (2013). Analisis Kemampuan Siswa Menyelesaikan Soal Matematika Dalam bentuk Cerita Pokok Bahasan Barisan dan Deret Pada Siswa Kelas XII SMA AL-Islam 3 Surakarta. Unpublished Thesis. Surakarta: Universitas Muhamma.

Ninik, Hobri, \& Suharto. (2014). Analisis Kemampuan Pemecahan Masalah Untuk Setiap Tahap Model Polya Dari Siswa ASMK Ibu Pakusari Jurusan Multimedia Pada Pokok Bahasan Program Linier. Kadikma, 5(3), 61-68. Retrieved from https://jurnal.unej.ac.id/in. https://doi.org/10.12681/er.9602

Nurohmah, S. D., \& Setianingsih, R. (2014). Implementasi Scaffolding untuk Mengatasi Kesulitan Siswa Kelas X SMK Kartika 1 Surabaya dalam Meyelesaikan Soal Cerita pada Materi Program Linear. MATHEdunesa: Jurnal Ilmiah Pendidikan Matematika, 3(3), 221229. Retrieved from https://jurnalmahasiswa.un.

Rosli, R., Goldsby, D., \& Capraro, M. M. (2013). Assessing Students' Mathematical Problem-Solving and Problem-Posing Skills. Asian Social Science, 9(16), 54-60. Retrieved from http://www.ccsenet.org/journ. https://doi.org/10.5539/ass.v9n16p54

Schoenfeld, A. H. (2014). Expert and Novice Mathematical Problem Solving. Journal for Research in Mathematics Education, 13(1), 256267. Retrieved from https://eric.ed.gov/?id=ED.

Vanderbei, R. J. (2015). Linear Programming: Foundation and Extensions. In New York: Springer. https://doi.org/10.1201/9781420010749

Wildana, W., Mustamin, S. H., \& Nur, F. (2016). Analisis Kesalahan Peserta Didik Dalam Menjawab Soal Program Linear Kelas XII IPA MAN 1 Makassar. MaPan, 4(1), 75-82. Retrieved from http://103.55.216.56/index.p.https://doi.org/10.24252/mapan.2016v4 n1a6 
46 | Nissa: Eksplorasi Kemampuan Siswa Memecahkan Masalah ... 